\title{
Interruptions: Testing the Rhetoric of Culturally Led Urban Development
}

\author{
Malcolm Miles \\ [Paper first received, August 2004; in final form, January 2005]
}

Summary. Since the 1980 s, the cultural industries have gained a key role in strategies to deal with urban problems, seen as able to provide a new economic base in post-industrial settings. Cases of flagship cultural institutions such as Tate Modern or the Guggenheim in Bilbao imply that a cultural turn in urban policy delivers urban revitalisation. Following the turn in Glasgow's fortunes after being European Capital of Culture in 1990, it is easy to understand how city authorities and developers alike are captivated by cultural projects. But there are questions: is advocacy for the creative industries to be trusted? To what extent can policies and strategies which are successful in one city be mapped onto others? And to what extent do cultural producers, such as artists, subscribe to the party line? An increasing number of voices of dissent in the arts suggest an alternative approach to urban regeneration. This paper questions the rhetoric of the cultural industries and investigates emerging alternative scenarios.

\section{Introduction}

Since the 1980s, in the UK and US, the arts (within a broader category of the cultural and creative industries) have gained a key role in strategies to deal with urban problems from social exclusion to the rehabilitation of post-industrial sites. Persuasive advocacy on the part of professionals and organisations within the cultural industries has been a factor in persuading governments that, in post-industrial situations, the cultural industries, and related knowledge sector of electronic communication and higher education, can provide a new economic base. A small number of successful cases tends to be advanced as evidence that a cultural turn in policies for urban renewal can deliver revitalisation of post-industrial cities. These cases often centre on a new flagship cultural institution. Examples include Tate Modern in London and the Guggenheim in Bilbao. In other cases, an entire district may be redesignated as a cultural quarter. Examples include the Rope Walks Quarter in Liverpool and El Raval in Barcelona. The latter also includes a flagship venue, the Museum of Contemporary Art, Barcelona (MACBA). Apart from drawing visitors into an area, such venues and recodings of a district tend to encourage a proliferation of small, broadly cultural businesses, from graphic design and architectural design firms to designer-bars and boutiques, all catering for a new cultural class, as it were.

Following the turn in Glasgow's fortunes after being a European Capital of Culture in 1990 , it is easy to understand how city authorities and developers alike are captivated by cultural projects. As Sharon Zukin notes: "so much of the dominant capitalist economy has ... undergone a cultural turn" (Zukin, 1996, p. 226). The allure of redeveloped 
waterfront sites such as Baltimore's harbour district, London's docklands or Cardiff Bay provides an aesthetic gloss for commercial schemes which frequently erase all traces of the histories of their sites. But there are difficulties. The recoding of a district as a cultural quarter may lead to gentrification-a shift from multiple to single occupancy and from rent to owner-occupation of housing being a key aspect of this - and a marginalisation (or peripheralisation) of dwellers who become constituted as a residual public. A cultural zone can easily be read as a zone of affluence. But setting that contentious (and complex) issue aside, there are still questions: is advocacy for the creative industries itself creative (like creative accounting)? And to what extent can policies and strategies which are successful in one city be mapped onto others in which conditions differ? As John Myerscough (1988) argues, Ipswich lacks the grounded cultural infrastructure of Glasgow and would not produce a similar return on the same culturally based investment. Similarly, while Barcelona is advanced as a model of a successful cultural economy (Degen, 2004), it remains exceptional on account of a unique cultural heritage and the political impetus to revive Catalan culture after the end of the Franco period, quite apart from a policy to attract cultural rather than mass-market tourism from the early 1990s onwards (Dodd, 1999). To see culture, with its legacy in liberal reformism of a universal benefit, as a universal solution to present-day urban problems may, then, be romantic.

I wonder, too, whether advocacy for the cultural industries as general problemsolvers is based on more than vested interest, or may represent a co-option of culture to the agenda of marketisation. My first aim, then, in this paper, is to reflect on the cultural turn in urban redevelopment. I start by reconsidering this cultural turn, asking what is meant by culture, examining aspects of culturally led urban redevelopment and asking whether Adorno's use of the term 'the culture industry' to denote an industry of mass deception remains valid. But my second aim-because I think cynicism is required in the present political and cultural climate, but is not by itself enough-is to ask how cultural producers such as artists might contribute critically to processes of urban change. I do this by looking at a small number of art projects which do not subscribe to the dominant agenda of culturally led urban redevelopment, but operate in urban settings. These are not widely known and tend to be absent in art journals (which foreground art in gallery spaces). Such projects may, however, offer an alternative form of cultural intervention to conventional public art.

\section{Voices of Dissent}

I am encouraged in this investigation by criticality on the parts of some artists working in urban situations today. This is the more interesting because many artists have gained material benefit from the cultural turn in urban policy through commissions for public art or the provision of new gallery spaces in which to exhibit their work. Among the dissenting voices are those of Sarah Carrington and Sophie Hope (the artist group B + B)

In the UK the integration of art into the Government's policy on social inclusion and regeneration relies heavily on utopian notions of art as an empowering tool ... The 'art pill' is now dished out by New Labour in an attempt to empower and effect change through the participatory values of art (www.welcomebb.org.uk).

George Yúdice observes a similar situation in the US

No longer restricted solely to the sanctioned arenas of culture, the arts would be literally suffused throughout the civic structure, finding a home in a variety of community service and economic development activities-from youth programs and crime prevention to job training and race relations-far afield from the traditional aesthetic functions of the arts (Larson, 1997, pp. 127-128; cited in Yúdice, 2003, p. 11). 
Yúdice points out that this is a defensive posture after attacks on the arts in Congress and threats to the survival of the National Endowment for the Arts (NEA), from whom the above was drafted. Multifunctionality in the arts mirrors multitasking in post-industrial patterns of flexible employment (see Sennett, 1998) and seems to be led by the arts funding system. B $+\mathrm{B}$ note complexities which interrupt the scenario of culturally led redevelopment. They argue that art's aesthetic distancing of reality offers either a critical space, or a resignation to the world as given (the better future reassigned to an aesthetic dreamland equivalent to Heaven); and that art subsumed to the agenda of a regime dedicated to marketisation will not retain a radical edge. Perhaps the art pill is a placebo. Perhaps the rhetoric is hollow.

My concern echoes Monica Degen's in her critique of the aestheticisation of spaces in Barcelona and Castlefield, Manchester (2002). And as a cautionary tale, I would cite the rebranding of the UK as Cool Britannia by New Labour after the 1997 election victory and the failure of the Millennium Dome (which I take in some ways as an emblem of Cool Britannia). The Dome and Tate Modern, while contrasting cases in terms of visitor numbers, are not far apart on the south bank of the Thames. Both are flagship cultural sites. Tate Modern has exceeded expectations of visitor numbers to become a key node of metropolitan cultural life, while the Dome attracted only a fraction of its intended numbers despite insistent media promotion and special offers on ticket prices. Tate Modern, of course, is free-although its café, restaurant and bookshop are not. Yet the oddest thing seems that Tate Modern has a collection of modern art, which is a specialist interest and for most an acquired taste, while the Dome attempted to display the supposedly universal qualities of the nation's values, spirituality, diversity and technological achievements. Tate has moved the cultural centre of London across the river (aided by a new bridge) but has done so less by converting the city's diverse publics to modern art than by becoming a new social space, a place to meet, eat, buy books and be seen. Tate is cool, and this results from a marketing exercise, but through an understatement which enables its publics to entertain the notion they have produced that cool themselves. It is the success of Tate Modern not the failure of the Dome which continues to attract public authorities and private developers alike to the strategy of culturally led urban redevelopment. But it may be the Dome which better represents the rhetoric of a universalised cultural intervention in national and urban life.

It may be also that interventions of a more specific and localised kind, as I read in the art projects I cite in the second part of the paper, have a greater resonance for those who encounter or participate in them. If so, perhaps for at least a few people, cultural work is a means to a new approach to the many problems which beset city dwelling in a post-industrial period.

\section{Urban Culture and Policy}

In this section, I begin by noting the ambiguities which attend the term culture. This begs the question as to what and in particular whose culture is utilised in urban redevelopment. I then examine the vicissitudes of culturally led urban redevelopment since the 1980s. Finally in this section, seeking an appropriate theoretical framework, I reconsider Adorno's argument on the culture industry as an industry of mass deception.

\subsection{Culture and Cultures}

There are ambiguities in the use of the term culture in strategies for culturally led urban renewal. Beginning The Cultures of Cities with a reference to cities as centres of culture, Sharon Zukin rehearses some of the term's uses

The Acropolis of the urban art museum or concert hall, the trendy art gallery and café, restaurants that fuse ethic traditions into culinary logos-cultural activities are supposed to lift us out of the mire of our 
everyday lives and into the sacred spaces of ritualized pleasures (Zukin, 1995, p. 1).

The list implies a series of social strata more complex than a set of social classes: a high art élite whose cultural capital may not equate with money capital; new bohemians, yuppies who like rubbing shoulders with artists and social others in cultural spaces; consumers of ethnic foods, who favour hybrid cuisines. Yet all are metropolitan types of some affluence. Absent from the list are those without access to consumption. Zukin writes, still, from a concern for social justice and her use of the term 'cultures' (rather than 'culture') in her title indicates a concern for the everyday ways of life which constitute culture in an anthropological context. This recognition of the ordinary informed the inception of cultural studies as an academic discipline in the 1960s and Zukin cites Raymond Williams' The Country and the City (1973).

Zukin's analysis of culturally led redevelopment in New York City affirms that culture in redevelopment tends to be Culture-the traditional high arts of the Metropolitan Museum or the avant-gardism of the Museum of Modern Art. This, she points out, does not mean that artists embrace the agenda of culturally led redevelopment, although their production feeds an industry in which the insertion of new cultural spaces raises the value of surrounding real estate while museum boards of trustees offer networking opportunities to developers. Zukin remarks that the cultural labour force depends on a range of ways to earn a living-making art and washing up in bars-and that many in the arts "are supposed to live on the margins ... used to deprivation" (Zukin, 1995, pp. 12-13). The growth of an arts infrastructure in the past two decades, and in the UK a significant increase in public funding for arts management since the 1990s, may have taken cultural managers into a more affluent lifestyle-able to eat in the restaurants which denote a cultural zone (in which it is more likely that immigrants rather than artists will wash dishes)_but a majority of artists who do not gain international reputations remain in a marginal economic category. But the culture of the cultured class is cultivated; it is like the cultivation of taste in the 18th century; it is equally a way of life expressing the value of culture (or culture as a value) in acts of cultural consumption which extend beyond the visual and performing arts to design and architecture, new media, food and drink, fashion and modes of transport.

What emerges is a meaning of culture specific to the spaces of post-industrial urban redevelopment. It bridges the anthropological (a way of life or, more carefully stated, a set of habits of everyday living which express and articulate a set of values) and the aesthetic (the arts and their appreciation by suitably educated minds). It is the culture of a class, diverse in background but with a disposable income, which uses cultural spaces. Walter Benjamin (1999) noted that the Paris arcades similarly housed a new class of windowshoppers and observers of others observing themselves.

\subsection{Culture in Redevelopment: Strategies and Attractions}

Part of Zukin's purpose is to draw attention to contestable and conflictual aspects of culture in a climate in which city authorities compete globally to rebrand their cities, in which image is all. She remarks that while culture offers ways to deal with difference it also "offers a coded means of discrimination, an undertone to the dominant discourse of democratisation" when styles which emerge at street-level-ripped jeans, for instance"are cycled through mass media, especially fashion and 'urban music' magazines ... where, divorced from their social context, they become images of cool" (Zukin, 1995, p. 9). I share Zukin's concern that "The cacophony of demands for justice is translated into a coherent demand for jeans" (p. 9). Recent advertising by Nike confirms the potential for marginalisation to be subsumed in consumption when urban basketball spaces, in Berlin as in New York, are signed by what look like municipal notices but are 
in fact elements in an advertising campaign relying on recognition by a target public (Goldman and Papson, 1998; von Borries, 2003). But if cultural consumption is a means to defuse dissent-Zukin comments that "culture is also a powerful means of controlling cities" (Zukin, 1995, p. 1)—for city authorities it may be more a competitive edge in a campaign for inward investment. By commissioning a highly visible piece of public art or employing an internationally recognised architect, a city may purchase a place on a notional international culture map. The decision by Barcelona's city authorities to site a World Trade Centre designed by I M Pei on its redeveloped waterfront denotes such intention to be a world city.

The specifics vary, but culturally led urban redevelopment tends to include the following: the insertion of a flagship cultural institution in a post-industrial zone, often a waterfront site, to lever private-sector investment in the surrounding area and attract tourism; the designation of a neighbourhood as a cultural industries quarter for small- and mediumsize businesses in the arts, media and leisure. The definition of what qualifies as a cultural industry varies, Allen Scott (2000) taking the broadest approach to include furniture manufacture, leather, perfume and other commodities alongside the arts and film in cities such as Los Angeles and Paris. For Myerscough (1988), the focus was more narrowly on the visual and performing arts and heritage; and for Charles Landry and Franco Bianchini (1995), it is the arts, media and cultural consumption which contribute to a creative city. Given that culturally led redevelopment occurs in deindustrialised conditions, it is not surprising that outposts of cultural recoding are geographically juxtaposed with areas of residual deprivation. Graeme Evans (2004, p. 71) notes that Hoxton in London, an area of multiple deprivation for many inhabitants, is also "the capital's trendiest area”. Like New York's SoHo in the 1980s, it combines a cluster of arts and media venues, including the White Cube Gallery in which the work of artists such as Antony Gormley is shown, with increasingly high-rent apartments. Evans remarks that the cultural industry quarter models currently promoted in urban regeneration "tend to neglect both the historical precedents and the symbolic importance and value of place and space" (Evans, 2004, p. 91). Citing Landry (2000), he argues elsewhere that the vogue for culture does not include broad representation of cultural producers or communities, which "mirrors the professionalisation and bureaucratisation of both cultural and other public policy realms and decision-making structures" (Evans, 2001, p. 277). The outcome is a growth in cultural infrastructure but not in support for cultural producers such as artists, writers and performers. Members of those groups may individually gain from the provision of new venues, but this does not in itself support the experimental, non-market-led production of new work. Further, many new cultural buildings in the UK were allocated capital funding from the national lottery on the basis of projected visitor numbers supplied by cultural industries consultants, but not revenue funding. One casualty of this system was the Earth Centre in Doncaster, on the site of a redundant colliery and employing redundant miners, which closed when visitor numbers failed to match targets which may have been unrealistic.

It seems that Tate Modern can capitalise on its occupation of a redundant industrial site, its ex-industrial building having "a fashionably squatted aspect" (Leslie, 2001, p. 3), but at the Earth Centre an imaginative response to environmental sustainability, with reed-bed water cleansing and gardens for arid places, fails in a less glamorous location more than two hours by rail from London. Tate Modern responded to employment needs in Southwark, one of London's poorest boroughs, through a training programme for local people which more or less guaranteed them an interview for jobs in security and catering, but the lesson remains that, first, capital projects do not always survive; and, secondly, although catering is the largest sector in Tate's employment it does not admit the operatives to the cultural realm or affluence of 
which the museum is an emblem. Failures such as that of the Earth Centre do not inhibit cultural industries advocates, any more than a lack of evaluation of benefits inhibited the commissioning of public art in the 1980s and early 1990s. According to Sara Selwood, in a book ironically titled The Benefits of Public Art (1995), the claims made for commissions and projects were largely so vague as to be undemonstrable. Public art gained from the fluency of its advocates - the arts breed effective verbal communication-and a willingness of government through the Arts Council to back campaigns for schemes such as Per cent for Art (through which a percentage, usually one, of capital budgets would be reserved for art and craft commissions or projects) and was in some ways a dry run for the success of cultural industries advocacy (Landry, 2000; Landry and Bianchini, 1995) in persuading municipal authorities to adopt notions of a creative city. There is a tendency to generalisation in statements such as

In a number of American [sic] cities, leading strategists of 'downtown rejuvenation' have argued that arts-led investment is the most efficient way of beginning the process of raising morale and developing 'atmosphere' in ... low-status and moribund districts (Bianchini et al., 1988, p. 14)

and to aestheticisation as in "Urban design is essentially about knitting together different parts of the city into a coherent artefact" (Landry and Bianchini, 1995, p. 28). This might be set beside Jane Jacob's remark that "a city cannot be a work of art" (Jacobs, 1961, p. 373; original emphasis).

\subsection{Contestable Terms}

A difficulty is that meanings of culture as the arts, a way of life and means of a symbolic economy may be fused as if they denote a unified concept. A further difficulty is that cultural policy tends to remain instrumentalist despite the insights of complexity theory (Byrne, 1997; Cilliers, 1998) that outcomes of a given intervention cannot be predicted in the way assumed in the rational planning model of the inter- and post-war periods, but will be affected by even minor shifts in conditions. This adds to the difficulty of mapping solutions from one city to another. A third difficulty is that the benefits of cultural redevelopment are unevenly distributed. I accept that cultural flagships can contribute to more confident perceptions of a city, including by some of its publics as well as investors or tourists. Writing on Glasgow in 1990, Peter Booth and Robin Boyle say that the opening of a new gallery for the Burrell Collection "was undoubtedly the catalyst that drew the different components together" (Booth and Boyle, 1993, p. 31). In the UK, cases such as Tate Modern, Tate of the North in Liverpool (to be European City of Culture in 2008), the Lowry Museum in Salford and the Baltic in Gateshead (with the nearby Sage centre for chamber music) can be advanced as having changed external perceptions of their sites. But, as the arts have moved in the UK from being administered as a public service to being managed as businesses paying their way in increased property values, job creation and tourism, so what is sometimes called urban regeneration (with an implication of community benefit) has become urban redevelopment. Rosalyn Deutsche (1996, pp. 49-109) notes the uneven benefits of redevelopment in New York when homeless people, some evicted as an outcome of gentrification, were cleared from spaces such as Grand Central Station by Mayor Koch. The art displayed in iconic cultural spaces meanwhile becomes emblematic of a new affluence, this reading displacing readings based on its histories of production and reception which include histories of dissent and refusal of art's commodification. Esther Leslie writes

Tate Modern is not just trendy, but in the vanguard of a reinvention of cultural spaces worldwide ... the expertise of art workers is leased out to business and education, with online gift shops, travel planning, digital reproductions for download and so on (Leslie, 2001, p. 3). 
In an uncanny mix of élitism and populism, Tate retains a role of interpreting modern visual culture in the selectivity of its exhibits and portraying itself as free of the class aspect of museum-going. It remains, however, an instrument of liberal reform, in its early days at Millbank having offered an education in taste and behaviour for the lower classes (Taylor, 1993) and today providing free admission to a modernised cultural ambience which may be no less subject to codes of behaviour-although the value to which the code lends coherence might now be consumption rather than liberal education. The modernisation of Tate, which for Leslie is marketisation, masks possible arguments as to whose culture is promoted, in the context of complex cross currents of class, race, gender and cultural as well as money capital. In other cases, too, cross-currents complexify the situation: Booth and Boyle (1993, p. 40) cite criticisms of Glasgow's Capital of Culture programme, promoted by Saatchi and Saatchi, as marginalising the city's working-class culture and emphasising cultural tourism to the detriment of support for local cultural producers; and Julia Gonzalez (1993, pp. 84-86) notes a contest of values between the internationalism of Bilbao's élites represented by the Guggenheim and a grassroots interest in the arts as articulating Basque nationalism. While Disney stands for a depoliticised global culture and Guggenheim is an international art venue brand, it may be that local cultures are both more politicised and under threat. Joost Smiers (2003, p. 103) reports, for instance, that "Little is left of the Egyptian film industry" as a result of a mix of factors including censorship, a boycott of Egyptian films by some Arab states after the country's separate peace with Israel and "competition with American [sic] products". He adds that "By the end of the 1980s Brazilian cinema had been all but destroyed ... from the results of the hegemony of the neoliberal project" (Smiers, 2003, p. 103). Still, when cities are sites of increased migration and the pervasive discourse is of difference, cultural dialogue offers a potential ground for contestation and a non-confrontational means to maintain a creative tension within difference.

In the 1970s, Raymond Williams saw in popular culture

a complex argument about the relations between general human development and a particular way of life, and between both and the works and practices of art and intelligence (Williams, 1976, pp. 80-81).

In 1995, Landry and Bianchini stated that

Ethnic ghettoes are unlikely to contribute to solving the wider problems of cities [while] New ideas can be generated through cultural crossovers, as in the success of young British Asians who have synthesised 'bhangra' music (Landry and Bianchini, 1995, p. 25).

Justin O'Connor sees cultural intermediaries (entrepreneurs in popular music, for instance) playing key roles in the new economies of sites such as Castlefield (O'Connor and Wynne, 1996; O'Connor, 1998). In another way, also addressing current urban conditions, the Creative Partnerships scheme funded by the UK government links artists with schools in which they are seen as injecting a creative energy which will have general benefit to the education system. In both cases-difference and education-the arts are perceived as catalysts to the solution of social problems. Yúdice (2003) outlines a parallel scenario in the US. This is an extension of the argument used for public art in the 1980s and early 1990s (Shaw, 1991), that public art contributes to place identity and acts as a catalyst for economic recovery. This might reflect a view that social problems, such as street crime, are produced by deprivation; arts advocates are adept at annexing new social agendas and governments seem glad to accept this. (Cynically, I would say because the arts are cheaper and arts projects easier to understand than deeper enquiry into social problems.) But the result, in an ethos which requires auditable outcomes for public expenditure, is that the solutions favoured tend to be in the form of cultural 
economies-new areas of consumption trading on cultural identities-rather than a regeneration of local cultures.

New terms are inserted in the argument but lack specificity, denoting a lack of specific understandings and a hegemony of topdown strategies which displace grassroots tactics. The term 'vibrancy', for instance, is used by Andrew Kelly in Bristol's (failed) bid to be a European Capital of Culture in 2008

For cities to develop, not just as regional centres, but on the national and international scale, they need to become culturally vibrant (Kelly, 2001, p. 16).

This is reminiscent of the Arts Council's An Urban Renaissance

The arts are crowd-pullers. People find themselves drawn to places which are vibrant and alive (Arts Council, 1989).

The publication asserts that the arts are a catalyst for regeneration, a magnet for tourism and business, enhance the visual quality of a city's environment and provide a focus for community and individual development. This is a succinct summary of what has become a well-rehearsed case. Like much cultural advocacy, it cites references to 'American' models without looking to the specifics of evidence. Similarly, City Centres, City Cultures, produced for the Centre for Local Economic strategies (CLES) in 1988 claims that

in many towns and cities the best strategic programme for improving the quality of life might well turn out to be based on developing a coherent and wide-ranging arts and cultural policy (Bianchini et al., 1988, p. 10).

But if in the 1980s cultural provision still had something of a public-benefit ethos, in the 1990s the market-led approach of modernisation has fed into it, so that Landry and Bianchini argue that "forming a well working public/private partnership is itself a creative act" (Landry and Bianchini, 1995, p. 51). Really?

\subsection{Marketisation or Public Benefit?}

Today's market emphasis contrasts with the public-benefit ethos of post-war liberalism in arts policy, even more with the social policy emphasis of the Greater London Council (GLC) in supporting community arts in the 1970s which extended the efforts of the Wilson government to democratise culture in the late 1960s. Jenny Lee, the first UK Arts Minister, echoed the concerns of workingclass intellectuals like Raymond Williams and Richard Hoggart by promoting regional policies and a

bridging of the gap between ... the 'higher' forms of entertainment and the traditional sources-the brass band, the amateur concert party, the entertainer, the music hall and pop group (Jenny Lee; quoted in Willett, 1967, p. 203).

But determination of cultural norms tends to remain with an arts bureaucracy which reproduces an older parochialism, so that access is widened to a culture predetermined in the image of the governing cultural body. Arts publics are thereby rendered passive receivers of culture rather than being empowered to shape cultures. This liberalreformist attitude persists in the findings of a panel chaired by architect Richard Burton in 1989-91 on the Per cent for Art policy. Burton's report seeks to make "contemporary arts and crafts more accessible to the public" and places "more interesting and attractive" (Shaw, 1991, p. 16) and relies on a universality of cultural value. John Willett complained in 1967 that "The weakness of the policy of the last twenty years is that it rests on assumptions which are very seldom discussed" (Willett, 1967, p. 220) and perhaps something similar could be said now, even if the assumptions have moved from public benefit to globalised consumption. Marketisation, however, is clothed in a new rhetoric of social development in which the arts are utilised as representing non-commercial (aesthetic) value at the same time as taking on an increasing range of social issues. There was a precedent to 
an extent in the uses of community arts projects, such as painting murals on the gable ends of housing terraces, in the 1960s and 1970s, but perhaps then the publics for such projects were more specifically identified than the cultural tourists or investors of today's urban rebranding, and more involved in production of the work.

The extent to which the arts are now seen as problem-solvers is seen in the statistics for Single Regeneration Budgets (SRBs) in the UK. Of 66 SRBs in England in 199899, 31 included a cultural project; linked funding from bodies such as English Heritage and the environmental charity The Groundwork Trust brought the total support for cultural projects in SRBs that fiscal year to more than $£ 100$ million (Selwood, 2001, pp. $60-65)$. This is in the context of a rise in government annual funding for the arts to an average of $£ 204.5$ million in the years 1994-99 (Selwood, 2001, p. 183). Culture in SRBs, in other words, generated a budget in 1998/99 equivalent to about half that of the arts in the public sector (although more than $£ 100$ million was added to the latter from sponsorship). These figures can be seen also in context of $£ 241.7$ million of national lottery money distributed by the Arts Council and more than $£ 300$ million distributed by the Heritage Lottery Fund in capital schemes many of which contributed flagship projects to post-industrial urban redevelopment.

That the urban cultural turn is not always based on evidence for sustainable benefits to a city's publics is shown in studies of Birmingham's rebranding of its central business district around Centenary Square as a cultural zone; jobs were created, but tended to be temporary, part-time and low-paid (Loftman and Nevin, 1998). But rather than deconstruct the socioeconomic case for the arts, I want to draw attention to another difficulty: the privileging of the visual in culturally led urban redevelopment, again citing Bristol. This might seem a tangential argument, but I want to draw a parallel between this and the prevailing top-down approach of culturally led urban redevelopment.

\subsection{Legibility or Interpretation from Above?}

Bristol's bid to be a Capital of Culture exemplifies this. Kelly revives Kevin Lynch's (1960) concept of legibility in a campaign for Bristol Legible City. A booklet produced to explain the concept states

Think of great cities and what makes them so distinctive, impressive and attractive. Without exception, the experience of the public realm - the quality of public spaces and the aesthetics of buildings and design_plays a huge part in shaping positive perceptions of a city (Bristol Legible City, 2001a).

Another interprets the aim through explanation of a new signage system across the city

It's about building an identity for Bristol that can grow beyond signs to encompass everything from bus shelters and kiosks to street furniture and sculpture, becoming a symbol of a confident and successful European city (Bristol Legible City, 2001b, p. 13).

Here, a public art programme provides landmarks and Kelly states that the Legible City project brings together for the first time in a British city "a multidisciplinary team ... to consider the issue of city identity and legibility" (Kelly, 2001, p. 36). The new signs feature maps of the immediate environs, using a traditional bird's-eye viewpoint. It would have been interesting to see a streetlevel visualisation of routes through the urban landscape, even more so to draw attention to the multisensory aspects of a city's streetscapes-the smells, textures, sounds and so forth. But my point was that the legible city is a visual city and this involves a power-relation which Doreen Massey draws out in Space, Place and Gender

It is now a well-established argument, from feminists but not only from feminists, that modernism both privileged vision over the other senses and established a way of seeing from the point of view of an authoritative, privileged, and male, position. The privileging of vision impoverishes us 
through deprivation of other forms of sensory perception. ... But, and more important ... the reason for the privileging of vision is precisely its supposed detachment. Such detachment, of course, can have its advantages, but it is also necessarily a 'detached' view from a particular point of view. Detached does not here mean disinterested (Massey, 1994, p. 232).

This is more than a by-pass of Kantian aesthetics; it is the imposition of the dominant, masculine viewpoint of the conventional city plan which uses an ability to see-over (or oversee) as a metaphor for having powerover and was developed as a form of cartography following Alberti's invention of a device to map accurately a city's streets from a viewpoint on its circuit of walls in the 15th century, but is not the only possible means to map a city.

I want to take this a little further before returning to the main argument, not least because it emphasises the relation of urban representation (of which cultural rebranding is an aspect) to power. French Marxist philosopher Henri Lefebvre (1991) theorised that all societies have characteristic spatial practices - the perpendicular roads of a Roman city with a standardised siting of key functions on the axis throughout the Empire, for example-and that these are ideological. He then differentiated what he called conceptual (or representational) space from lived spaces (of representation). Conceptual space is epitomised by the architect's drawing, the town plan and the architectural metaphor used by Descartes when he writes, in his Discourse (1637), of an 'engineer' drawing regular places. Conceptual space is constituted by a unified, consistent and coherent system of signs-such as Cartesian co-ordinateswhich, from another viewpoint, reduces the world to that system as if reality, if it exists, is only represented by it and cannot be directly experienced. In one way, conceptual space allows all kinds of operations which would otherwise be impossible, like planning a city and then building it according to a plan which the builders cannot see on the ground (but according to which they are directed). It can also be argued that there is no possibility to articulate raw experiences, only to 'cook' them (to use a term from Levi-Strauss) through language. In another way, however, conceptual space marginalises what Lefebvre calls lived spaces (plural), the spaces of and around the body, of association and memory, of desire and hope, of shifting meanings, overlaid, as it were, on the spaces of buildings and streets, cutting at times through the grain of the vista. But Lefebvre (1991, pp. 78-79) is at pains to point out that lived spaces, even in Tuscany at the time in which perspective was invented, remain accessible to rural and urban dwellers. In extraordinary circumstances such as the toppling of the Vendôme Column during the Paris Commune of 1871, the reproduction of meanings which takes place (and precedence) in the routines of daily life and labour is interrupted by a production of new meanings in liberatory acts (which reenact a shift of power as in the destruction of a statue of the figurehead of the deposed power).

I would read the visual city, and the legible city, despite its progressive aspects as proposed by Lynch, as that produced in a universalised conceptual spatial realm and the city of multisense impressions, multiple and overlapping actualities, as produced in somatic spaces. Lefebvre does not see these as separate but as superimposed and complementary realms.

I am left asking why Kelly chose to base his campaign on Lynch more than 40 years after publication of The Image of the City. It may be that Kelly's approach reflects the assumptions of that era in other ways-notably in giving primacy to professionals rather than dwellers in the determination of his envisaged City of Culture. The arts advocacy of the 1980s, which sought the inclusion of art in the built environment and promoted artistdesigned street furniture, likewise retained a profession-based model of urban change. There were proposed links between planners, architects, engineers, designers and artists, but limited recognition of the tacit expertise of dwellers on dwelling. If, in the 1960s, 
then, legibility was a progressive idea in dealing with the spaces between buildings which signature architecture ignored, it emphasised design and, for me, is out-dated by the 1990s literature of an architectural everyday informed by Lefebvre (Borden et al., 1996; Harris and Berke, 1997; Cline, 1997; Hill, 1998; Wigglesworth and Till, 1998). Bristol Legible City sought to integrate the work of regional, national and international artists' and designers' in a longterm programme to "make the city easier to understand and more familiar" (Bristol Legible City, 2001b, p. 13) but the accent is on designing things rather than the informal and often invisible traces of occupation which constitute a familiarity of urban spaces for many dwellers. Looking around Bristol's cultural zone, the Harbourside area, today I find, crossing an artist-designed bridge, life-size bronzes of famous Bristolians Thomas Chatterton, William Penn and Henry Cabot, to whom Cary Grant was later added, in a theme park developed by a publicprivate finance initiative (perhaps the kind of creative partnership envisaged by Landry and Bianchini). These statues reproduce exclusions of race and gender in defining the public sphere; I doubt that doing away with plinths changes the power relations involved.

What does happen, familiarly, is that tourists photograph each other sitting (or walking for Cary Grant) next to the famous old men, hoping to find a little rubbed-off star-dust in the snapshots. In a not dissimilar way, claims for universal benefit in culture inform a tendency to universal solutions to urban problems, supposing that benediction is given from a position of power. This is despite departures from the conventional power relation of professional to dweller ('user', as Lefebvre critically employs the term) in radical planning (Sandercock, 1998) and the shift of allegiance from a public benefit to a market-led ethos in arts management and urban redevelopment. The cultural terrain remains all-encompassing in the scope attributed to it and continues to privilege the visual sense through a primacy of image and dominance of design professionals in the implementation of the images designed. Zukin sees such reductiveness "to a coherent visual representation" as a common element of culturally led redevelopment schemes, so that

culture as a 'way of life' is incorporated into 'cultural products', i.e. ecological, historical, or architectural materials that can be displayed, interpreted, reproduced, and sold in a putatively universal repertoire of visual consumption (Zukin, 1996, p. 227).

\section{And Bianchini writes that}

There are conflicts between ... maintaining prestigious facilities for 'high' culture marketed to wealthy visitors which emphasize 'exclusiveness', and ... opening up popular access to them (Bianchini, 1993, p. 19).

Flagship schemes, as he continues, enhance a city's competitiveness while grassroots culture requires a decentred approach, so that the former tends to be supported at the cost of the latter. Similarly, Gonzalez writes of Bilbao that its culturally led redevelopment relies on

ephemeral spectacles, aimed at attracting and encouraging the development of local cultural industries [so that culture is] expressed in the language of economics and would serve economic development objectives (Gonzalez, 1993, p. 85).

And Jude Bloomfield writes of Bologna

It has proved easier to solve the problems of the new middle-class youth by enabling them to become cultural entrepreneurs than that of bridging the gap between them and the poorly skilled and alienated underclass (Bloomfield, 1993, pp. 111112).

Zukin argues that the power to create an image of a city has increased in importance when social classes and political parties

have become less relevant mechanisms of expressing identity. Those who create 
images stamp a collective identity. Whether they are media corporations like the Disney Company, art museums, or politicians, they are developing new spaces for public cultures (Zukin, 1995, p. 3).

Elsewhere, she concludes that

Far from suggesting a free expression of divergent identities, the flourishing of new cultural meanings in the highly competitive environment of urban space makes it more urgent to understand their material effects (Zukin, 1996, p. 242).

From a similarly critical position, in the UK, artists' group Hewitt + Jordan-artists Andy Hewitt and Mel Jordan, based in Sheffieldwrite

Cultural policy can be divisive. Culture-led regeneration is only representative of a wider constituency and wider culture of the city when it is developed alongside a social policy that stems from a vigorous and democratic political process. This demands a political system that has the confidence to take on and discuss the bigger and longer-term problems affecting the city (Hewitt + Jordan, 2004, p. 29).

I doubt this system is currently available in the UK or US. The result is that cultural production is co-opted by developers and governments alike to provide badges of respectability for practices which may produce social division rather than equity. The use of culture in culturally led urban development trades on culture's supposed universal value to render its commissioning beyond contest while redevelopment itself may be highly contestable, as in the construction of what Jon Bird (1993) has called 'Dystopia on the Thames' in London's docklands. Landry and Bianchini assert that "Seemingly superficial, 'cosmetic' interventions can have an important effect on morale" (Landry and Bianchini, 1995 , p. 31), but is the effect sustainable? Urban regeneration implies a social base and may not be open to top-down or design solutions, or creativity takes resistant forms. Rose Gilmore notes a poster which people are invited to copy and display in protest against increased penalties for flyposting, in the Rope Walks Quarter of Liverpool: "THIS IS CULTURE” (Gilmore, 2004, p. 128).

\subsection{The Cultural Industries or the Culture Industry?}

Writing in the 1940s, Teodor W. Adorno and Max Horkheimer (1947/1997) refused the term 'mass culture' because it was agreeable, as Adorno later recalls, to the proprietors of an industry of mass deception. It may seem odd that I introduce this, having criticised Kelly for reviving Lynch. A historical adjustment is required in reading Adorno. After cultural studies, from the Birmingham School in the 1960s onwards, his rejection of intermediate art forms such as film and jazz seems quaint. For cultural studies, any area of cultural production-comics to Racine-is useful in articulating the received or contested values of a period. This has never meant that a play by Racine is equal aesthetically to graffiti, but recognises the specifics of aesthetic criteria in context of their social production; and allows that intervention in the production of categories is an intervention in the production of society. Adorno's refusal of the term mass culture is an example of such intervention. His critique is conditioned also by the Nazis' closure of the Frankfurt Institute for Social Research and its reinstitution at Columbia University, New York; and if the spectre which haunts the Frankfurt School as a whole is the rise of fascism in industrialised Germany after the failure of the German Revolution in 1919, the prevailing condition which inflects Adorno's work in the 1940s is his exposure, as a European intellectual Jewish Marxist, to the movies, radio and the popular press in the US. Part of his response was a detailed interrogation of the horoscope column of The Los Angeles Times (Adorno, 1994, pp. 34-127) in which he writes that the advice given

implies that all problems due to objective circumstances such as, above all, economic 
difficulties, can be solved in terms of private individual behaviour or by psychological insight (Adorno, 1994, p. 57).

Perhaps this could inform a reconsideration of the cultural industries. This is not an argument against psychological, or more specifically psycho-analytic, investigations of urban cultural experiences (see Sibley, 2001, for such an approach), but draws attention to the non-deliberative ways in which culture is consumed. Whether consumers are dupes of the market or knowing manipulators of the manipulation it offers them is the subjectmatter of a considerable literature in sociology (see Oh and Arditi, 2000, for a summary of positions). For Adorno it is the former; but for Walter Benjamin cinema offers audiences imaginative opportunities to remake the plot in awareness of the alienating labour of actors who make a film in multiple takes. But Benjamin did not go to the movies but to Paris, and to Moscow in the 1920s to see experimental theatre and film as vehicles of revolution. It is more that Adorno and Benjamin are writing about different things than that they disagree; Adorno's rejection of mass culture is not undermined by Benjamin's celebration of a democratic lens.

Benjamin's work is more often used in cultural studies teaching. His essay on 'The work of art in an age of technical reproducibility', to use a correct translation of the title (Benjamin, 1970, pp. 219-254; see Leslie, 2000, p. 132) is a standard text. Possibly more interesting is his address to a group of anti-fascist writers in Paris in 1934, published as 'The author as producer' (in Benjamin, 1983) in which he alludes to the contributions of readers as authors in the Soviet press, a case of mass culture in which the medium is reclaimed by its public. Again, his experience differs from Adorno's, listening uncomfortably to the reduction of classical music to easy listening on the wireless. It is to Adorno that I turn nonetheless because his refusal of the term 'mass culture', reiterated in a reconsideration of the 1947 essay in 1975 (Adorno, 1991, pp. 85-92), is key to my critique of today's cultural policy.
In approaching this material, nonetheless, I need to be selective. For example

The culture industry fuses the old and familiar in a new quality. In all its branches, products which are tailored for consumption by masses, and which to a great extent determine the nature of that consumption, are manufactured more or less according to plan ... The culture industry intentionally integrates its consumers from above. To the detriment of both it forces together the spheres of high and low art, separated for thousands of years (Adorno, 1991, p. 85).

This extract links a critique of the culture industry as dominating the consumption of cultural products with a concern that high and low art forms are fused. A limitation of Adorno's position is that high art cannot be produced by, only for, its public by specialist interpreters. The point I take, however, is that mass culture is mass deception and begins in the term mass culture as if it is produced by consumers while the hold over broadcasting technology by commercial radio stations in the US in the 1940s, Hollywood over the movies and companies such as Disney and Time-Warner over global media now, means that cultural consumption is determined not by listeners and viewers but by the owners of the means of production.

The market, not social need, drives industries such as film and fashion, and increasingly subsumes high art (see Leslie's comment on Tate Modern above). Adorno's argument seems valid when he writes that "The entire practice of the culture industry transfers the profit motive naked onto cultural forms" (Adorno, 1991, p. 86). It is not a surprise: the function of industry, cultural or otherwise, in capitalism is to increase wealth, not make people happy. Yet the culture industry gives an illusion of choice in adherence to a conformity determined by the market and-bearing in mind the discussion above-a by-product of the culture industry is an image of a conflict-free society which masks divergences of power and need the negotiation or 
contestation of which are legitimate aspects of public, political and cultural concern.

On the former, Adorno writes in 'The Schema of Mass Culture', published in German in 1981

The dream industry does not so much fabricate the dreams of the customers as introduce the dreams of the suppliers among the people. This is the thousand-year empire of an industrial caste system governed by a stream of never ending dynasties (Adorno, 1991, p. 80).

There is a resonance: empire translates as reich. The passage recalls this from the 1940s

The culture industry perpetually cheats its consumers of what it perpetually promises. The promissory note which ... it draws on pleasure is endlessly prolonged; the promise, which is actually all the spectacle consists of, is illusory: all it actually confirms is that the real point will never be reached, that the diner must be satisfied with the menu (Adorno and Horkheimer, 1947/1997, p. 139).

Adorno recognises the liberating bourgeois characteristic of intrigue in drama-a way to renegotiate the conditions of a subject's life-but remarks that when heroes no longer make sacrifices or come of age, but achieve a success which affirms conformity, the intriguer is liquidated. He writes that mass culture "treats conflict but in fact proceeds without conflict ... reality becomes a technique for suspending its development"; and that "Mass art registers this fact inasmuch as it repudiates conflict as outmoded" (Adorno, 1991, pp. 62, 66). I put this beside Zukin's argument that when

labour unions and political parties seem powerless to challenge social divisions, culture as 'collective lifestyle' appears a meaningful, and often conflictual, source of representation [while culture is] often reduced to a set of marketable images (Zukin, 1995, p. 263).

And Ian Angus' comment that mass culture replaces a divided class-based culture "with a single self-enclosed world of industrially produced cultural goods" so that, as cultural uniformity drives out regional, ethnic and linguistic difference, inequalities are "expressed not as different worlds of goods, but as relative degrees of access to uniform goods" (Angus, 2000, pp. 89-90). I would cite, too, remarks by a dissident cultural professional in Glasgow

The wish locally to bury the facts of a past which had become inconvenient and to superimpose a new, sanitised, marketable image of the city required not a critical social history ... but a bland, selfcongratulatory hype (quoted in Bianchini, 1991, p. 37).

Why reintroduce critical theory in urban studies? It lacks an empirical base (and I have suggested arts advocacy suffers from this condition) and offers only a discursive, dialectical approach to material problems. An underpinning theme in Adorno's writing (1997) is the tension between art's aesthetic and social dimensions, (dis)coloured by a view that in dark times art, too, will be dark in as much as it critically conveys the absurdities of the administered world. For Adorno, the plays of Samuel Beckett stand for such a response. Yet, if Beckett is as acquired a taste as modern art, the concern is with consciousness (and conscience); it is also with dialectics - the insight that while people are shaped by conditions they also intervene in and reshape the conditions which shape them. Put more simply, Benjamin's idea of the author as producer, and citizen as co-author, can be adapted to express an idea of the dweller as co-producer of urban spaces. This is compatible with, if different from, Lefebvre's reflection on lived space. In brief, then, I would argue that the method of interrogation advanced by Adorno can be applied to culturally led urban redevelopment and that part of his critique retains validity in that context (of mass deception then and the illusions of cultural consumption and the commodification - as aestheticisation-of urban spaces now). 


\section{Art as Interruption}

Despair is easy-the more so after reading Adorno-but observing artists' groups working against the grain of cultural universalism gives me hope. The work is seldom a resolution of a situation, more often it problematises one. Matthew Cornford and David Cross, as the London-based group Cornford and Cross, describe their aim as to

incite individuals to collude in encroachments upon their own freedom in the urban environment, and so critically engage with the relationship of art to the exercise of power in public space (quoted in Neilson et al., 2004, p. 26).

They do not seek a mass public but to engage specific publics for whom imaginative possibilities are opened.

To give an example of the kind of project I have in mind, Hewitt + Jordan produced a billboard text for a site at the corner of Corporation Street and Alma Street, Sheffield, in April, 2004 which states that "The economic function of public art is to increase the value of private property" (Hewitt + Jordan, 2004, p. 53; see Figure 1). The artists see the work as setting out "to question the function of art in the public realm within the economic regeneration of post industrial cities" (www.jordan-hewitt.demon.co.uk). It is the second part of a project which began with the artists presenting themselves to delegates at a conference in London in 2003 as the prize in a raffle. Both works were commissioned by Public Art Forum, a network of agencies, public authorities and individuals involved in public art's management. Hewitt + Jordan do not make documentary objects out of such projects-in the way Andy Goldsworthy, say, relies on gallery-shown colour photographs of works in remote places to bring them to a public and make a living as an artist — and state

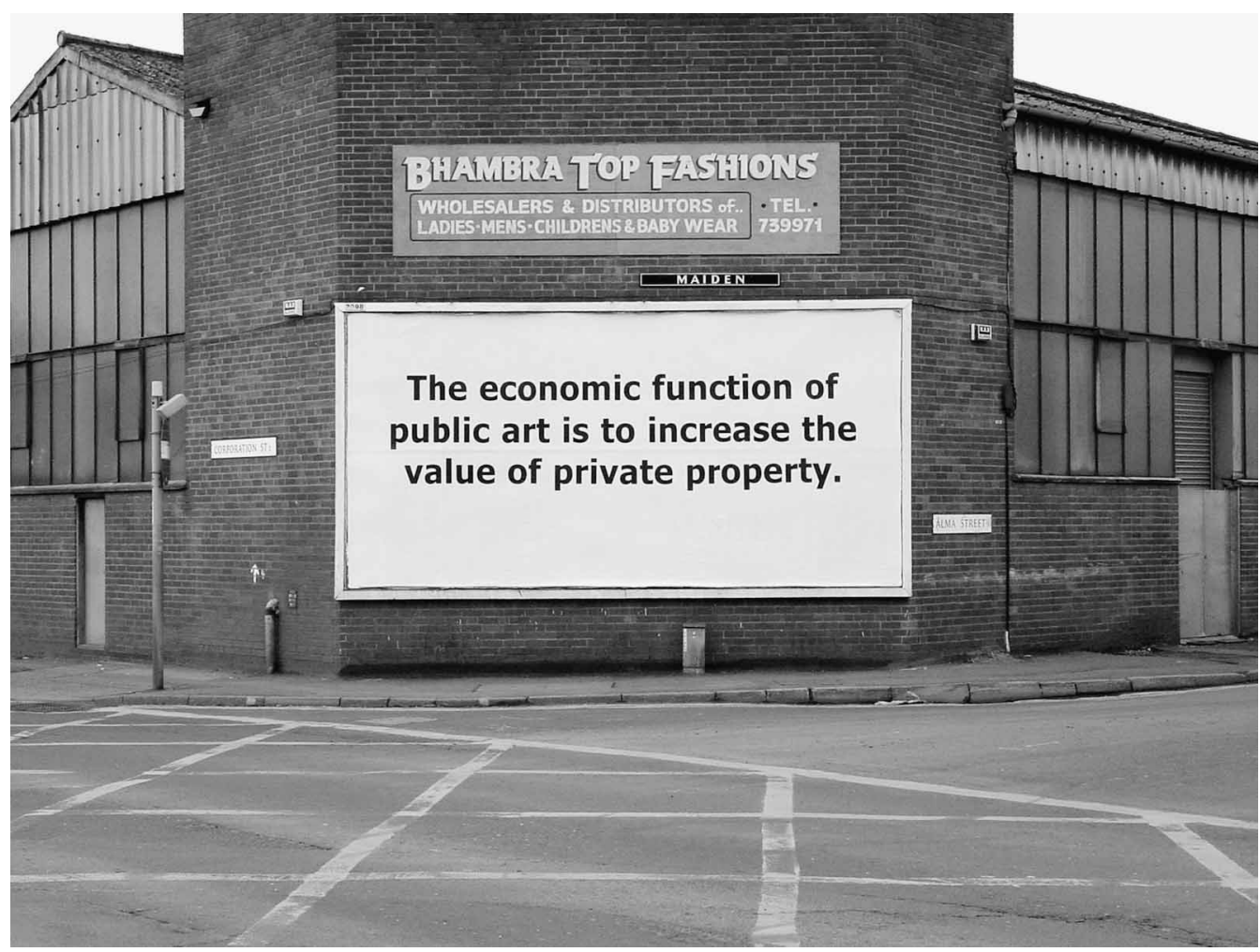

Figure 1. The economic function of public art is to increase the value of private property. By courtesy of the artists Hewitt and Jordan. 
We always try to avoid making something - not even a video-not that we can make video anyway. We know that we are making it difficult for ourselves. I think that the reason for this is a desire to focus the attention on the intervention/process itself rather than on an object-an object brings 'relief' to the normal spectator of art (Hewitt + Jordan, 2004, p. 47).

In a more recent project, Futurology, Hewitt + Jordan commissioned a range of other artists to work in partnership with schools in the West Midlands and arranged a series of critical discussions of culture at the New Art Gallery in Walsall. The project was supported by Creative Partnerships, but Jordan and Hewitt saw it as, in itself, a critique of the intention for which Creative Partnerships was established by government: to "encourage creative learning in schools" (Futurology, 2004). Rather than ask what is uncreative learning I quote the project leaflet

Current government believes this form of learning will help a future citizen adapt to the changing economic environment. Creative Partnerships is aimed at bringing this learning initiative to schools in areas that are the most "economically and socially challenged' ... We want to avoid both the cynical withdrawal of artists from the public as well as the naïve surrendering of the artist to the agenda of politicians and funders (Futurology, 2004).

That agenda tends to employ artists as lowbudget problem-solvers, sometimes putting them in situations in which they have little chance to contribute-through short-term and peripatetic involvement-to structural problems which may in any case result from other government policies. In a conversation, Hewitt and Jordan mentioned that a byproduct of Creative Partnerships and other socially directed schemes is a worry on the part of government arts officers that there is a lack of evidence that quantifiable benefits accrue (conversation with the author, 11 August 2004, Walsall). This seems to be a rerun of the problem identified by Selwood
(1995) and could offer a reclamation of the autonomy characteristic of Modernism in the arts, or imply a deeper questioning of the conditions in which social dis-ease arises. Hewitt + Jordan look to a reformed autonomy

The fact that our practice attempts to be about some idea of art's transformation $\ldots$ is also crucial to this idea of the autonomy of art. But I don't mean that in the sense of wanting it to be outside everyone's experience... There are good things about being autonomous too-like an objective view and a dissident voice (Hewitt + Jordan, 2004, p. 44).

Jordan, speaking there in an interview, does not adopt an activist position but one of seeking to change art rather than the world, as a possible means to change part of the way in which the idea of a world (distinct from the bio-realm of Earth) is constructed. Patricia Phillips, from a different viewpoint, writes of new modes of practice in north America which have

produced a variety of social, political, and activist forms-installations, interventions, roundtables, performances, and multiple forms of collaboration that engage urgent subjects (housing and homelessness, social justice, domestic violence, race and class, forgotten histories and untold stories) in a passionate, of eclectic hybridity (Phillips, 2003, p. 12).

In the UK, too, a range of eclectic and hybrid practices has begun to emerge. The work of the London-based group PLATFORM (Jane Trowell, James Marriott, Dan Gretton and Emma Sangster) links art to democracy and ecology. The group have as many links to campaigning organisations as to the artworld and refuse to follow the agendas of arts funding bodies regardless of what has at times been a fluctuating financial position. Their current preoccupation is with the global impact on human and environmental rights of the oil industry and projects have included production and distribution to commuters of a spoof newspaper and guided 
walks around the financial district of London (see Miles, 2004a, pp. 195-203).

If PLATFORM politicises the fantasy of an ever-expanding global economy which is materially destructive of human rights and natural habitats on a correspondingly global scale, there is also work which interrupts the rhetoric of urban development in a localised way-such as Camelot, a project by Cornford and Cross, comprising an industrially made steel security fence erected around a residual patch of grass near the bus station in Stokeon-Trent in 1996. During its installation, the project caused huge resentment of its form, which obstructed informal paths to the shopping centre, and of the use of public money to pay for it. It could have been (and was for some) a public relations disaster. Yet it led to intensive discussions on the quality and ownership of public spaces in the city and their neglect by the local authority, discussions which were perhaps elements of a more direct democracy than that of local elections. The artists state

Camelot is a literal interpretation of the City Limits theme; we chose to invite reflection and debate on the physical and social boundaries which often determine the patterns of city life-in this case by denying people access to some small, neglected fragments of public urban land (artists' statement; in Miles, 2004a, p. 166).

This makes any audit of the work as might be required on conventional public art problematic and denies the kind of solution-based evaluation which was required in, for instance, SRB-funded projects and is now required for Creative Partnerships. Indeed, I have only the word of one of the artists involved as to what took place.

An implication, tacit or stated, of such work is that it contributes to conditions in which radical socioeconomic change is possible. There are at least two ways in which to interpret this: either the change is personal-as the personal is political-and occurs in more or less intimate exchanges between artists and micro-scale, participating audiences, in which context PLATFORM arrange events on the parallel worlds of the oil industry and the management of the Holocaust for groups of around eight; or intervention is in the categories and conventions of discourse in order to shift how specific issues are represented or (re)considered. The former might rely on a latent utopianism which is part of modern culture's heritage, but this needs scrutiny. Above, I cite Hope and Carrington, the group $\mathrm{B}+\mathrm{B}$, on the reliance of the integration of art into the current UK government's policy on social inclusion and regeneration on such utopian notions of art as empowerment (www.welcomebb.org.uk). They also note that Joseph Beuys reframed art therapeutically to empower people to live creatively, which I take to include imagining futures other than those prescribed by capital or its out-sourced providers of governmental services in a globalised economy. But what Beuys meant by creativity is not what is meant in government policy, in what Hope and Carrington call the art pill. B+B further cite Alan Kaprow, who built 30 ice walls in Pasadena and Los Angeles in 1967 as dystopian spectacles resembling capitalism.

The approaches sketched here denote a stratum of cultural production which crosses the boundaries of art and social formation, and becomes a form, too, of cultural mediation when artists take responsibility for the dissemination of their own projects. It probably no longer matters whether such activity is classified as art, except that artists need arts funding (or jobs in arts education) for support even when they set out to critique such support systems. A future project for Hewitt + Jordan is to distribute 422300 badges-one for everyone-in Manchester saying "I will not accept 'the way things are" (badge in author's possession). Is it cool or should I note Arundhati Roy's complaint that, as a writer taking sides over the construction of highly destructive dams in India, "that's considered a pretty uncool, unsophisticated thing to do ... uncomfortably close to the territory occupied by political party ideologues" (Roy, 2001, p. 11)? Does cultural engagement correspond to the agenda of the World Commission on Culture 
and Development, for whom cultures are "ways of living together" (UNESCO, 1996, p. 14), more than to that of developers and cultural institutions? Perhaps we can think of cultural work in which production and reception link in participatory ways of working as development in the sense of development in the non-affluent world, where NGOs have sometimes been able to take more empowering approaches than those of urban policy in the affluent world (Guha and Martinez-Alier, 1997, for example). But that is another enquiry and might begin by looking at culturally led redevelopment via the literatures of sustainability and development studies. I note a summary of the World Commission's report

One of the most basic freedoms is to be able to define our own basic needs. This freedom is threatened by a combination of global pressures and global neglect ... Awareness of this has led to resurgent assertions in the post-Cold War world, as people and their leaders turn to their own culture as a means of self-definition and mobilisation. For the poorest among them, their own values are often the only thing that they can assert ... The concern is that development has meant loss of identity, sense of community and personal meaning (UNESCO, 1996, p. 15).

There are traces of cultural liberalism in UNESCO, yet the report begins to separate culture as way of life, but also as action, from the demands of a globalised economy and the culture it produces, and requires, in order to glue that economy together and keep it going. Culture, after all, is arguably more influential in establishing brand loyalties by turning products into iconic representations of an alluring lifestyle than simple advertising (although that is one channel by which the representation is enforced, of course). Looking to the literatures of development in the non-affluent world, where the term 'development' is brought into contestation in debates on sustainability, more radical approaches are found than in most of the reports, schemes and image-constructions of urban redevelopment in the affluent world. The concept of liberation ecology, to take a particularly interesting case, is a discourse of Nature which is "Marxist in origin, poststructural in recent influence, politically transformative in intent, but subject still to the fiercest of debates" (Peet and Watts, 1996, p. 37). I wonder if the concept can be mapped onto the affluent world to subvert its notions of development, whether culturally or economically led. In the non-affluent world, the affluent world's notion of development as mono-crop agriculture is increasingly rejected by aid agencies for whom handing over management to local groups is imperative if solutions to environmental degradation are to be lasting. Summarising the position, Elliott writes

Ensuring that individual land users and communities have secure rights to resources and the benefits from investments therein is a further condition of sustainable agricultural development based on recent experiences of success (Elliott, 1999, p. 126).

Could that be applied to deprivation in an inner-city area? It would perhaps not produce the solution advanced naively in 1995 by Landry and Bianchini for the revitalisation of urban centres

In Newcastle they have used the Happy Hour ... On various days of the week, some bars and restaurants reduce their prices substantially in order to encourage people to stay in the city centre and use its facilities. The prices are so low that it is hardly worth going home and cooking your own food (Landry and Bianchini, 1995, p. 42).

In Newcastle, too, and in several other city centres in the UK, police chiefs now seek additional powers to curb the effects of excess alcohol consumption among young people attracted there by, precisely, happy hours. The dream of oblivion may be more easy than most to market and has the advantage of perpetual non-satisfaction in consequent amnesia, but is a degradation of urban 
dwelling equivalent, for the same profit motive, to, say, logging in Indonesia. My conclusion - it may be inept to venture a conclusion in discussion of a process which I have said from complexity theory is unpredictable-is that the values of the contemporary art cited above are more akin to those of the work of some NGOs in the non-affluent world, or of activists resisting globalised capital and its environmental destructiveness and human rights abuses, than to those of urban redevelopment in the affluent world or modern art.

A key component in this is the handing over to participants of co-production of the work. A similar departure is found in radical planning when the planner retains her/his expertise but relinquishes the safety of both statistics and the office to spend time with mobilised community groups. Sandercock writes that

Radical practices emerge from experience with and a critique of existing unequal relations and distributions of power, opportunity, and resources (Sandercock, 1988, p. 97).

It is important to note that radical planners and activist artists do not cease to be planners and artists but do accord equal value to both the expertise of professionals in their fields and dwellers on dwelling. These practices interrupt the flow of city-image rhetoric. Moments of close conversation on the architectures of power, say, during a guided walk through London's financial district are not given to city marketing, any more than a city which is promoted as having no grand design to articulate its narrative will attract mainstream investment. Neither are the activities of Cornford and Cross likely to put Stoke on the international culture or tourism maps. Their provocation of reconsiderations of the values of the public realm contrast with fantasies of a latte-drinking, piazza-sitting society. It could be compared with the work of the Yes Men, Andy Bichlbaum and Mike Bonano, exmedia teachers, who construct an ironic critique of global trade by impersonating it via a spoof World Trade Organisation websitefrom which they are invited to address business gatherings. A press report notes that, impersonating (or identity correcting, as they put it) a representative of McDonalds for a student audience, Bonano

strolls over to his overhead projector and begins to outline his firm's latest act of corporate responsibility: converting first-world human waste into fast food for developing countries (Burkeman, 2004).

After two decades of public art, the integration of artists in the design of highways and bridges, their complicity in publicprivate finance initiatives and the view that culture solves socioeconomic problems which may result from other areas of public policy, I find that refreshing.

But I need to ask one more question: is the approach I cite above another form of cultural expediency differing only in specifics from its predecessors, just as much avant-garde art since the 19th century reproduced the conventions (such as the privileged insight of the artist) of the social arrangements it sought to overthrow? Yúdice writes

In our era, representations of and claims to cultural difference are expedient insofar as they multiply commodities and empower community (Yúdice, 2003, p. 25).

Is radical culture, then, a resource? As such, it must let go of the Modernist claim to autonomy even within radical contemporary art practice. At the same time, it retains the equally Modernist claim to deal in privileged insights. Yúdice traces, from Foucault, an evolution of a relation between thought and the world (episteme) in which the postEnlightenment phase is characterised by heterodox enquiry and a redemption of "great hidden forces" (Foucault, 1973, p. 251, quoted in Yúdice, 2003, p. 30). Yúdice continues

Modern knowledge thus consists of unveiling the primary processes (the infrastructure, the unconscious) that lurk in the depths, beneath the surface: manifestations of ideology, personality, and the social (Yúdice, 2003, p. 30). 
and proposes a next phase in which previous modes (resemblance, representation and historicity) are recombined to account for "the constitutive force of signs". The rupture of society predicted in Marxist analyses of capitalism is salved by cultural expedients and "the transformation of artists and intellectuals into managers of that expropriation under the guise of 'community-based' work" (Yúdice, 2003, p. 35). The prognosis is as gloomy as Adorno's

That culture as resource is at the heart of these processes does not mean that capital's assault on workers and others ... [is] merely virtual. It is for this reason that cultural politics ... is unlikely to make a difference. Indeed, I argue ... that the 'cultural left' is largely enjoined to perform such a cultural politics ... The protection of the cultural resources that global entertainment conglomerates have expropriated involves not only the law but also the use of police and military forces, for example, in the pursuit of piracy ... From the perspective of most forms of cultural politics ... subversion of the assumptions implicit in dominant media as a way of appropriating them is thought to be a viable option ... [but] it is hardly effective (Yúdice, 2003, pp. 35-36).

His inclination, as I read it, is that music piracy is a more frontal assault on capitalism than the kinds of intervention I have sketched above. Interestingly, music piracy is both an extension and a counter to the entrepreneurial activities of the cultural intermediaries O'Connor sees as vitalising new urban spaces.

In the end, I admit I cling to hope because a world without it is too awful to contemplate, not from evidence. But then Zukin reports that

the belief that New York is the world capital of culture has been used as if it were a fortune-teller's benediction to ward off all evidence of economic decline (Zukin, 1995, p. 110).

Nonetheless, I look to art which takes a dialectical approach as a viable alternative to either complicity in or frontal resistance to globalised capitalism and its cultural turn. For Jane Trowell this work has "a viral quality, slipping a proposition into the bloodstream under the guise of a safe publication" (Trowell, 2000, p. 107). Perhaps the spoof newspaper and the spoof website which mimic in order to refuse the appearances of an increasingly total neo-liberalism, appearances which today have the function of the deceptions of the culture industry previously, are interventions in the texture of globalised communications, interrupting its gloss and acting, almost imperceptibly, like frost in concrete. Perhaps that is what is viable now.

\section{References}

Adorno, T. W. (1991) The Culture Industry: Selected Essays on Mass Culture, Ed. by J. M. Bernstein. London: Routledge.

Adorno, T. W. (1994) The Stars Down to Earth and Other Essays on the Irrational in Culture, Ed. by S. Crook. London: Routledge.

Adorno, T. W. (1997) Aesthetic Theory, trans. by H. Hullot-Kentor. London: Athlone.

Adorno, T. W. and HorkHEIMER, M. (1947/1997) Dialectic of Enlightenment. London: Verso.

Angus, I. (2000) Primal Scenes of Communication: Communication, Consumerism, and Social Movements. Albany, NY: State University of New York Press.

Arts Council (1989) An Urban Renaissance. London: Arts Council.

Bell, D. and JaYne, M. (2004) City of Quarters: Urban Villages in the Contemporary City. Aldershot: Ashgate.

Benjamin, W. (1970) Illuminations, Ed. by $\mathrm{H}$. Arendt. London: Fontana.

Benjamin, W. (1983) Understanding Brecht. London: Verso.

Benjamin, W. (1999) The Arcades Project, Ed. by H. Eiland and K. McLaughlin. Cambridge, MA: Harvard University Press.

BenNeTt, S. and BuTLER, J. (Eds) (2000) Locality, Regeneration \& Diversities. Bristol: Intellect Books.

Bianchini, F. (1991) Alternative cities, Marxism Today, June, pp. 36-38.

Bianchini, F. (1993) Remaking European cities: the role of cultural policies, in: F. BIANCHINI and M. Parkinson (Eds) Cultural Policy and Urban Regeneration: The West European Experience, pp. 1-21. Manchester: Manchester University Press.

Bianchini, F. and Parkinson, M. (Eds) (1993) Cultural Policy and Urban Regeneration: The 
West European Experience. Manchester: Manchester University Press.

Bianchini, F., Fisher, M., Montgomery, J. and Worpole, K. (1988) City Centres, City Cultures. Manchester: Centre for Local Economic Strategies.

BIRD, J. (1993) Dystopia on the Thames, in: J. Bird, B. Curtis, T. Putnam et al. (Eds) Mapping the Futures, pp. 120-135. London: Routledge.

Bird, J., Curtis, B., Putnam, T. et al. (Eds) (1993) Mapping the Futures. London: Routledge.

Bloomfield, J. (1993) Bologna: a laboratory for cultural enterprise, in: F. BIANCHINI and $M$. PARKInSON (Eds) Cultural Policy and Urban Regeneration: The West European Experience, pp. 90-113. Manchester: Manchester University Press.

Booth, P. and Boyle, R. (1993) See Glasgow, see Culture, in: F. BIANCHINI and M. PARKINSON (Eds) Cultural Policy and Urban Regeneration: The West European Experience, pp. 21-47. Manchester: Manchester University Press.

Borden, I., Kerr, J., Pivaro, A. and Rendell, J. (Eds) (1996) Strangely Familiar: Narratives of Architecture in the City. London: Routledge.

Borries, F. von (2003) Consumption and the post-industrial city: Nike Town, in: M. Miles and N. Kirkham (Eds) Cultures \& Settlements, pp. 75-86. Bristol: Intellect Books.

Bristol Legible City (2001a) From Here to There. Bristol: Bristol Legible City.

Bristol Legible City (2001b) You Are Here. Bristol: Bristol Legible City.

Burkeman, O. (2004) The Bush baiters, The Guardian, review section, 2 November, p. 8.

Byrne, D. (1997) Chaotic places or complex places? Cities in a postindustrial era, in: S. Westwood and J. Williams (Eds) Imagining Cities: Scripts, Signs, Memories, pp. 50-72. London: Routledge.

Cilliers, P. (1998) Complexity and Postmodernism: Understanding Complex Systems. London: Routledge.

Cline, A. (1997) A Hut of One's Own. Cambridge, MA: MIT Press.

Degen, M. (2002) Regenerating public life? A sensory analysis of regenerated public places in El Raval, Barcelona, in: J. RUGG and D. HinCHCLIFFE (Eds) Recoveries and Reclamations, pp. 19-36. Bristol: Intellect Books.

Degen, M. (2004) Barcelona's Games: the Olympics, urban design, and global tourism, in: $\mathrm{M}$. SHELLER and J. URRY (Eds) Tourism Mobilities: Places to Play, Places in Play, pp. 131-142. London: Routledge.

Deutsche, R. (1996) Evictions: Art and Spatial Politics. Cambridge, MA: MIT Press.
DodD, D. (1999) Barcelona, the making of a cultural city, in: D. Dodd and A. VAN Hemel (Eds) Planning Cultural Tourism in Europe: A Presentation of Theories and Cases, pp. 53-64. Amsterdam: Boekman Stichting.

Dodd, D. and Hemel, A. van (Eds) (1999) Planning Cultural Tourism in Europe: A Presentation of Theories and Cases. Amsterdam: Boekman Stichting.

Elliott, J. (1999) An Introduction to Sustainable Development, 2nd edn. London: Routledge.

Evans, G. (2001) Cultural Planning: An Urban Renaissance? London: Routledge.

Evans, G. (2004) Cultural industry quarters: from pre-industrial to post-industrial production, in: D. BELL and M. JAYNE (Eds) City of Quarters: Urban Villages in the Contemporary City, pp. 71-92. Aldershot: Ashgate.

Foucault, M. (1973) The Order of Things: An Archaeology of the Human Sciences. New York: Vintage.

Futurology (2004) Project leaflet produced by Hewitt + Jordan, The New Art Gallery, Walsall.

Gallagher, A., Phillips, A. and Renton, A. (Eds) (2004) Tales of the City. Bologna: Arte Fiera 2004.

GiLmore, A. (2004) Popular music, urban regeneration and cultural quarters: the case of the Rope Walks Quarter, Liverpool, in: D. BELL and M. JAYNE (Eds) City of Quarters: Urban Villages in the Contemporary City, pp. 109-130. Aldershot: Ashgate.

Goldman, R. and PAPSON, S. (1998) Nike Culture. London: Sage.

GonZalez, J. M. (1993) Bilbao: culture, citizenship and quality of life, in: F. BIANCHINI and M. PARKinson (Eds) Cultural Policy and Urban Regeneration: The West European Experience, pp. 73-89. Manchester: Manchester University Press.

Gottdiener, M. (Ed.) (2000) New Forms of Consumption: Consumers, Culture, and Commodification. Lanham, MD: Rowman \& Littlefield.

Guha, R. and Martinez-Alier, J. (1997) Varieties of Environmentalism: Essays North and South. London: Earthscan.

Hall, T. and Hubbard, P. (Eds) (1998) The Entrepreneurial City: Geographies of Politics, Regime and Representation. Chichester: Wiley.

HARris, S. and Berke, D. (Eds) (1997) Architecture of the Everyday. New York: Princeton Architectural Press.

HewitT + Jordan (2004) I Fail to Agree. Sheffield: Site Gallery.

HiLl, J. (Ed.) (1998) Occupying Architecture. London: Routledge.

JACoBs, J. (1961) The Death and Life of Great American Cities. New York: Random House. 
Kelly, A. (2001) Building Legible Cities. Bristol: Bristol Legible City.

LANDry, C. (2000) The Creative City: A Toolkit for Urban Innovators. London: Earthscan.

LANDRY, C. and Bianchini, F. (1995) The Creative City. London: Demos.

LaRson, G. O. (1997) American Canvas. Washington, DC: National Endowment for the Arts.

Lefebvre, H. (1991) The Production of Space. Oxford: Blackwell.

LesLIE, E. (2000) Walter Benjamin: Overpowering Conformism. London: Pluto.

LesLIE, E. (2001) Tate Modern: a year of sweet success, Radical Philosophy, 109, pp. 2-5.

Loftman, P. and Nevin, B. (1998) Pro-growth local economic development strategies: civic promotion and local needs in Britain's second city, 1981-1996, in: T. HALl and P. HubB ARD (Eds) The Entrepreneurial City: Geographies of Politics, Regime and Representation, pp. 129-148. Chichester: Wiley.

Lynch, K. (1960) The Image of the City. Cambridge, MA: MIT Press.

MARCUSE, H. (1937/1968) The affirmative character of culture, in: Negations, pp. 88-133. Harmondsworth: Penguin.

Massey, D. (1994) Space, Place and Gender. Cambridge: Polity.

Merrifield, A. and Swyngedouw, E. (Eds) (1996) The Urbanization of Injustice. London: Lawrence \& Wishart.

Miles, M. (2000) The Uses of Decoration: Essays in the Architectural Everyday. Chichester: Wiley.

Miles, M. (2004a) Urban Avant-gardes: Art, Architecture and Change. London: Routledge.

Miles, M. (2004b) Drawn and quartered: El Raval and the Haussmannization of Barcelona, in: D. BELL and M. JAYNE (Eds) City of Quarters: Urban Villages in the Contemporary City, pp. 37-55. Aldershot: Ashgate.

MiLes, M. and KiRKhAM, N. (Eds) (2003) Cultures \& Settlements. Bristol: Intellect Books.

Myerscough, J. (1988) The Economic Importance of the Arts in Britain. London: Policy Studies Institute.

Neilson, E., Davies. L.-R. and Offers, S. von (2004) Cornford and Cross, in: A. Gallagher, A. Phillips and A. Renton (Eds) Tales of the City, pp. 26-27. Bologna: Arte Fiera.

O'Connor, J. and Wynne, D. (Eds) (1996) From the Margins to the Centre: Cultural Production and Consumption in the Post-Industrial City. Aldershot: Ashgate.

O'ConNor, J. (1998) Popular culture, cultural intermediaries and urban regeneration, in: T. Hall and P. HubBard (Eds) The Entrepreneurial City, pp. 225-240. Chichester: Wiley.
OH, M. and Arditi, J. (2000) Shopping and postmodernism: consumption, production, identity, and the Internet, in: M. GotTdiener (Ed.) New Forms of Consumption: Consumers, Culture, and Commodification, pp. 71-92. Lanham, MD: Rowman \& Littlefield.

PeEt, R. and Watts, M. (Eds) (1996) Liberation Ecologies: Environment, Development, Social Movements. London: Routledge.

Phillips, P. (2003) Unsettled sites: suspended attention. How is the city an issue for art?, in: L. Palmer (Ed.) 3 Acres: The Lake Du Sable Park Proposal Project, pp. 12-15. Chicago, IL: White Walls.

Roy, A. (2001) Power Politics. Cambridge, MA: South End Press.

RugG, J. and HinchCliffe, D. (Eds) (2002) Recoveries and Reclamations. Bristol: Intellect Books.

SANDERCOCK, L. (1998) Towards Cosmopolis. Chichester: Wiley.

Scott, A. J. (2000) The Cultural Economy of Cities. London: Sage.

Selwood, S. (Ed.) (1995) The Benefits of Public Art. London: Policy Studies Institute.

Selwood, S. (Ed.) (2001) The UK Cultural Sector: Profile and Policy Issues. London: Policy Studies Institute.

SEnNeTt, R. (1998) The Corrosion of Character: The Personal Consequences of Work in the New Capitalism. New York: Norton.

Shaw, P. (1991) Percent for Art: A Review. London: Arts Council of Great Britain.

Sibley, D. (2001) The binary city, Urban Studies, $38(2)$, pp. 239-259.

Smiers, J. (2003) Arts Under Pressure: Promoting Cultural Diversity in the Age of Globalization. London: Zed Books.

TAYLOR, B. (1993) From penitentiary to temple of art: early metaphors of improvement at the Millbank Tate, in: M. PoInTon (Ed.) Art Apart: Art Institutions and Ideology across England and North America, pp. 9-32. Manchester: Manchester University Press.

Trowell, J. (2000) The snowflake in hell and the baked alaska: improbability, intimacy and change in the public realm, in: S. BENNETT and J. ButLer (Eds) Locality, Regeneration \& Diversities, pp. 99-109. Bristol: Intellect Books.

UNESCO (1996) Our Creative Diversity: Report of the World Commission on Culture and Development (summary version). Paris: UNESCO.

Universal Forum of Cultures 2004 (nd) Project brochure. Barcelona: Universal Forum of Cultures-Barcelona 2004.

Westwood, S. and Williams, J. (Eds) (1997) Imagining Cities: Scripts, Signs, Memories. London: Routledge. 
Wigglesworth, S. and Till, J. (1998) The everyday and architecture, Architectural Design, profile 134, July/August.

Willett, J. (1967) Art in a City. London: Methuen.

Williams, R. (1973) The Country and the City. London: Chatto and Windus.

Williams, R. (1976) Keywords: A Vocabulary of Culture and Society. Harmondsworth: Penguin.
YÚDICE, G. (2003) The Expediency of Culture: Uses of Culture in the Global Era. Durham, NC: Duke University Press.

Zukin, S. (1995) The Cultures of Cities. Oxford: Blackwell.

ZuKIN, S. (1996) Cultural strategies of economic development and the hegemony of vision, in: A. Merrifield and E. Swyngedouw (Eds) The Urbanization of Injustice, pp. 223-243. London: Lawrence \& Wishart. 